УДК 342.95

DOI https://doi.org/10.32837/pyuv.v0i1.736

\author{
В. П. Лещинський \\ orcid.org/0000-0002-3916-0146

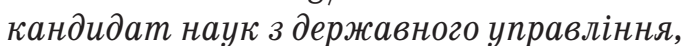 \\ Київський національний університет будівниитва та архітектури
}

\title{
СИСТЕМА ГАРАНТІЙ ЗАКОННОСТІ ДОЗВІЛЬНОЇ ДІЯЛЬНОСТІ: ЗАСАДИ ТА ПЕРСПЕКТИВИ РОЗВИТКУ
}

Сьогодні є очевидним превалювання позитивістського підходу законодавця щодо врегулювання відносин у сфері дозвільної діяльності. Проте актуальне зближення природно-правових та позитивістських підходів у сфері дозвільної діяльності дає змогу врахувати надбання щодо гарантій правової законності під час визначення гарантій законності у сфері здійснення дозвільної діяльності. При цьому іманентне прагнення правового позитивізму до чіткості та визначеності закріплених правових норм, а також специфіка містобудівної діяльності зумовлюють необхідність подальшого розвитку законодавчого закріплення наведених гарантій.

Проблематика системи гарантій законності дозвільної діяльності з урахуванням специфіки сфери містобудування не отримала належної уваги у наукових публікаціях. Дотичними тематиками варто вважати: засади здійснення дозвільної діяльності, проблематику законності у публічному адмініструванні та державному управлінні, окремі напрацювання філософсько-методологічного характеру, зокрема стосовно розкриття сутності системного підходу та деякі інші. Зокрема, слід відзначити роботи таких учених, як В.Б. Авер'янов, Е.Ф. Демський, О.В. Джафарова, М.С. Каган, О.В. Кузьменко, Р.В. Ленівський, І.Є. Марочкін, І.Л. Невзоров, Ю.С. Педько, П.М. Рабінович, А.О. Селіванов.

Метою статті є визначення актуальних засад системи гарантій законності дозвільної діяльності з урахуванням специфіки сфери містобудування, визначення на цій основі перспектив подальшого розвитку цієї системи.

Сьогодні склалися досить усталені наукові погляди щодо системи гарантій законності. Так, О.Ф. Скакун виділяє загальносоціальні та спеціально юридичні гарантії правової законності. Загальносоціальними вона визначає: політичні, економічні, соціальні, ідеологічні. До спеціальносоціальних (юридичних) гарантій відносяться: юридичні умови, правові способи, організаційно-правові засоби. Так, політичними гарантіями є: рівень демократії, політичного плюралізму, дотримання принципу поділу влади тощо. Юридичними умовами правової законності визначається якісний стан чинного законодавства, а також офіційних актів, пов'язаних із правозастосуванням.
Правовими способами визначено досконалість законодавства, сумлінне здійснення нагляду та контролю за станом правової законності, діяльність щодо попередження та припинення протиправної діяльності тощо [1, с. 496-497].

Виділення вдосконалення законодавства у сфері дозвільної системи окремим напрямом дозвільної діяльності зумовлюе і виділення особливих гарантій законності у цій сфері. Високий фаховий рівень такої діяльності зумовлює підвищені вимоги й до гарантій у цій сфері. Зокрема, неякісний підбір членів робочої групи щодо розроблення змін до чинного законодавства може мати критичне значення. Аналогічно - матеріальне та інше забезпечення такої діяльності.

О.Ф. Скакун виділяє міжнародні гарантії правової законності, під якими розуміє діяльність суб'єктів міжнародного права щодо контролю за дотриманням прав людини у конкретних сферах суспільних відносин, застосування санкцій чи заохочень у зв'язку із дотриманням або порушенням державами своїх міжнародних зобов'язань у певних сферах [1, с. 497-498]. У контексті дозвільної діяльності необхідно вказати про таких суб'єктів, як, наприклад, Європейський суд із прав людини. Хоча в Конвенції про захист прав людини та основоположних свобод $[2 ; 3]$ не передбачено прав, що безпосередньо стосуються дозвільної системи, але закріплено права, що можуть порушуватися внаслідок неналежного здійснення дозвільної діяльності суб'єктом публічної влади. Такими можна визначити право на: свободу думки, совісті і релігії (ст. 9) у разі відмови зареєструвати релігійну організацію; свободу вираження поглядів (ст. 10) - у разі відмови зареєструвати відповідну діяльність; свободу зібрань та об'єднань (ст. 11) - у разі відмови у реєстрації професійної спілки; заборону дискримінації (ст. 14). Отже, після вичерпання національних засобів захисту таких прав особа може звернутися за їх захистом до Європейського суду з прав людини.

Прикладами інших суб'єктів є суб'єкти прийняття міжнародних документів, що містять стандарти адміністративної діяльності, в тому числі і у сфері дозвільної системи. Так, органами співробітництва України та Європейського Союзу $€:$ Комітет із парламентського співробітництва, Комітет з питань співробітництва, Рада з питань співробітництва [4, с. 169]. 
Основу законодавства у сфері дозвільної діяльності становлять, зокрема, такі нормативні акти, як Закон України «Про дозвільну систему у сфері господарської діяльності» від 06.09.2005 р. № 2806-IV (далі - Закон України «Про дозвільну систему у сфері господарської діяльності») [5], Закон України «Про дозвільну діяльність у сфері використання ядерної енергії» від 11.01.2000 p. № 1370-XIV [6]. Проте є значна кількість інших законодавчих та підзаконних актів. При цьому особливими засадами правового регулювання у сфері дозвільної діяльності є досить широке коло питань, що визначаються виключно законами: випадки необхідності одержання дозвільних документів; суб'єкт видачі таких документів; оплатність дозвільної діяльності; строк видачі дозвільного документу та деякі інші (ч. 1 ст. 4 Закону України «Про дозвільну систему у сфері господарської діяльності»).

Вихідною ознакою правового позитивізму є обмеження змісту права виключно закріпленими у встановленому порядку нормами. При цьому зміст таких норм не обов'язково має співвідноситися 3 такими поняттями, як мораль та справедливість [7, с. 669-670]. Сьогодні спостерігається поступове зближення позицій правового позитивізму та природного права. Одним із виявів такого зближення є позиція так званого «м'якого позитивізму», відповідно до якої певний мінімум природно-правового змісту є умовою чинності легально встановлених приписів. Набувають поширеності й інші підходи, в яких правовий позитивізм поєднується з окремими формами соціологічного підходу у праві, або ж правового реалізму [7, с. 672].

3 наведеного можна зробити висновки щодо превалювання позитивістського підходу законодавця щодо врегулювання відносин у сфері дозвільної діяльності. Такий висновок вбачається у такому. По-перше, у чіткому визначенні сфер суспільних відносин, в яких здійснюється дозвільна діяльність (господарська діяльність та діяльність щодо використання ядерної енергії). В інших сферах необхідно казати про надання адміністративних послуг. По-друге, у жорсткій прив'язці до рівня нормативних актів, якими мають врегульовуватися засади здійснення дозвільної діяльності, визначення конкретних засад. Такий підхід законодавця необхідно повністю підтримати, з огляду на значення дозвільної діяльності як для держави (є інструментом державного управління у сфері суспільних відносин iз винятковим суспільним значенням), так і для особи (виникнення, зміна, припинення суб'єктивних прав, на відміну від адміністративних послуг, надання яких тільки створює умови для реалізації вже існуючих суб’єктивних прав).

Такий висновок звертає увагу на необхідність розвитку гарантій законності у сфері дозвільної діяльності. Зокрема, в юридичній літературі відзначається іманентне прагнення правового позитивізму до чіткості та визначеності закріплених правових норм. Крім того, відзначається особлива роль законослухняної поведінки, довіра до встановленого правопорядку [7, с. 672]. Вказане впливає й на визначення гарантій законності у правовому позитивізмі (в його історичній або «жорсткій» формі). Зокрема, з положень, що наводяться І.Л. Невзоровим стосовно радянської сутності законності, можна дійти висновку про iii етатистську теоретичну модель у цей період. Основною гарантією такої законності виступає загроза застосування державою примусу у разі невиконання легально встановлених норм [8, с. 39].

Актуальне зближення природно-правових та позитивістських підходів у сфері дозвільної діяльності дає змогу врахувати надбання щодо гарантій правової законності при визначенні гарантій законності у сфері здійснення дозвільної діяльності.

Зокрема, наведені вище положення щодо чіткості та визначеності встановлених норм зумовлює особливе значення такої гарантії, як якісне законодавство у сфері дозвільної діяльності (юридична умова законності). Такий пріоритет, як орієнтація на законослухняну поведінку, звертає увагу на високу виконавську дисципліну посадових осіб суб'єктів публічної влади. В умовах розвиненого позитивістського регулювання дозвільної діяльності дієвим засобом забезпечення цього є наявність дієвого контролю та нагляду у сфері дозвільної діяльності.

Сьогодні є поширеною класифікація гарантій законності за критерієм найближчої мети - на охоронні та захисні. Охоронні спрямовані на недопущення протиправної діяльності в майбутньому або недопущення настання негативних наслідків правопорушень, що вчиняються. Захисні спрямовані на усунення наслідків вже вчинених правопорушень, відновлення порушених прав, покарання правопорушника [1 с. 498]. Коментуючи такий підхід, необхідно вказати на наукову позицію щодо функцій правосуддя, одна 3 яких полягає у запобіганні подальшим конфліктам, що досягається за рахунок передбачуваності у вирішенні правових спорів [9, с. 383]. Тому виділені захисні гарантії мають одночасно й значний превентивний вплив, що наближує їх до охоронних. Проте безпосередня мета їх здійснення (розгляд правового спору, притягнення до юридичної відповідальності тощо) зумовлює істотну специфіку правових конструкцій відповідних суспільних інститутів. Виходячи з цього, доцільним є приділення окремої уваги зазначеним гарантіям.

Виокремлення захисних гарантій зумовлюється історичним розвитком цієї категорії. Так, ще у 70-х роках минулого століття П.М. Рабінович 
виокремлював гарантії відновлення законності поряд із засобами їі втілення та охорони [10, с. 236].

У сучасній науці адміністративного права виділяється така категорія, як засоби забезпечення законності, та виділяються їх такі основні групи, як: контрольна діяльність; реагування суб'єктів публічної влади на звернення приватних осіб щодо захисту їх суб'єктивних прав, свобод, законних інтересів; судовий захист вказаних прав, свобод, законних інтересів; притягнення особи до юридичної відповідальності [11, с. 350].

О.Ф. Скакун виділяє такі захисні гарантії законності, як: компенсація понесених особою збитків; відновлення суб’єктивного порушеного права; понесення правопорушником покарання [1, с. 498]. Необхідно вкзаати, що зазначені вище адміністративно-правові засоби забезпечення законності фактично відповідають за своїм призначенням захисним гарантіям правової законності.

Загальновідомою є теза щодо реалізації суб'єктами публічної влади своїх владних повноважень виключно у формі, встановленій законом [12, с. 268]. Зазначене не є виключення і щодо застосування окреслених засобів.

Процесуальна форма реалізації суб'єктами публічної влади своїх повноважень є одним із найбільш широко досліджуваних напрямів у науці адміністративного права. Адже саме у зв'язку із цим утворилася така галузь адміністративного права, як адміністративний процес. У зв'язку із цим необхідно вказати на наукові напрацювання В.Б. Авер'янова [11], Е.Ф. Демського [13],О.В. Кузьменко [14], Ю.С. Педька [15], А.О. Селіванова [16] та інших.

Виходячи 3 наведених та інших аспектів застосування терміна «гарантії», не буде помилкою стверджувати про визначення у сучасній теорії права гарантій як певних засобів, спрямованих на забезпечення належного існування та розвитку певних правових явищ. Однією з визначальних та відмежувальних ознак певного явища як системи є виділення його мети або призначення, для досягнення чого воно функціонує як система [17, с. 13]. 3 цього погляду кожен із наведених адміністративно-правових засобів може бути представлений як окрема гарантія законності у сфері здійснення дозвільної діяльності.

Таким чином, можливо попередньо виділити такі гарантії, як: контрольна діяльність; реагування суб’єктів публічної влади на звернення приватних осіб щодо захисту їхніх суб'єктивних прав, свобод, законних інтересів; судовий захист вказаних прав, свобод, законних інтересів; притягнення особи до юридичної відповідальності. Усі наведені гарантії реалізовуються у визначеній законом процесуальній формі.
Проте такий поділ підлягає уточненню. Зокрема, виділення притягнення до юридичної відповідальності як самостійна категорія зумовлене специфічним змістом категорії «адміністративно-правові засоби забезпечення законності» порівняно із гарантіями, оскільки перша категорія має більш виражений прикладний, практичний зміст, передбачає виділення власних ознак, яким мають відповідати явища, що становлять такі засоби [18, с. 32, 34-35]. Категорія ж «гарантії», з огляду на свою широту, передбачає розгляд правових явищ у їх власному сенсі, без обмеження їх вихідного змісту. В аспекті адміністративної відповідальності зазначене зумовлює можливість врахування іï матеріально-правового складника, що полягає у застосуванні до правопорушника передбачених законом засобів - адміністративних стягнень [19, с. 288]. Необхідно вказати, що правомірна поведінка досягається безпосередньо саме застосуванням адміністративної відповідальності, а не процедури притягнення до неї. Процедура у цьому значенні може розглядатись як адміністративно-правовий засіб, але не як самостійна гарантія. Отже, стосовно забезпечення законності у сфері дозвільної діяльності необхідно говорити про комплексну гарантію - адміністративна відповідальність.

Отже, систему гарантій законності дозвільної діяльності становлять: загальносоціальні гарантії; юридичні гарантії. Особливу групу, що частково вбирає в себе загальносоціальні, а частково - юридичні гарантії, становлять міжнародні гарантії законності у сфері дозвільної діяльності. Загальносоціальними гарантіями законності у сфері дозвільної діяльності є: політичні, економічні, соціальні та ідеологічні гарантії. Юридичними гарантіями законності виступають юридичні умови, правові способи та організаційно-правові засоби. Міжнародні гарантії становить діяльність суб'єктів міжнародного права, спрямована охорону прав і свобод людини у сфері дозвільної діяльності. Окреслені гарантії мають охоронний характер, тобто спрямовані насамперед на запобігання протиправній діяльності у цій сфері.

Окрему групу гарантій забезпечення законності у сфері дозвільної діяльності становлять захисні гарантії забезпечення законності у сфері дозвільної діяльності, що застосовуються у разі вчинення правопорушення. Вони передбачені нормами як адміністративного матеріального права (адміністративна відповідальність), так i адміністративного процесуального права (адміністративні юрисдикційні провадження: судові та позасудові). Такі гарантії виділено у контексті насамперед дозвільної правозастосовної діяльності.

Позитивістські засади дозвільної діяльності зумовлюють особливе значення окремих юридичних гарантій законності у сфері дозвільної 
діяльності - юридичних умов (якісне законодавство) та правових засобів (контроль, в тому числі міжвідомчий, та нагляд у досліджуваній сфері). Уточнення місця та значення вказаних гарантій у виділеній системі становиить перспективний напрям подальших наукових досліджень.

\section{Iimepamypa}

1. Скакун О.Ф. Теорія права і держави : підручник. Київ : Алерта; КНТ; ЦУЛ, 2010. 520 с.

2. Конвенція про захист прав людини та основоположних свобод від 04.11.50 p. № ETS № 005. Офіиійний вісник України. 2006. № 32 (23.08.2006). Ст. 2371.

3. Про ратифікацію Конвенції про захист прав людини і основоположних свобод 1950 року, Першого протоколу та протоколів № 2, 4, 7 та 11 до Конвенції : Закон України від 17.07.1997 № 475/97-ВР. Офіиійний вісник України. 1997. число 29, с. 10.

4. Стандарти європейського врядування : навч. посіб. / авт. кол. : І.А. Грицяк, О. Ю. Оржель, С. М. Гладкова та ін. ; за заг. ред. І. А. Грицяка. Київ : НАДУ, 2011. $184 \mathrm{c.}$

5. Про дозвільну систему у сфері господарської діяльності : Закон України від 06.09.2005 р. № 2806-IV . Офіиійний вісник України. 2005. № 39 (14.10.2005). Ст. 2429.

6. Про дозвільну діяльність у сфері використання ядерної енергії : Закон України від 11.01.2000 р. № 1370-XIV. Офіиійний вісник України. 2000. № 7 (03.03.2000). Ст. 242.

7. Велика українська юридична енциклопедія: у 20 т. Харків : Право, 2017. Т. 2 : Філософія права / редкол. : С. І. Максимов (голова) та ін. 1128 с.

8. Невзоров И.Л. Принцип законности в правоприменительной деятельности: дис. ... канд. юрид. наук: 12.00.01. Нац. ун-т внутр. дел. Харьков, 2002. 196 с

9. Організація судових та правоохоронних органів / за ред. І. Є. Марочкіна. Харків : Право. 448 с.

10. Рабинович П.М. Упрочение законности - закономерность социализма. Вопросы теории и методологии исследования. Львов : Вища шк. Изд-во при Львов. ун-те, $1975.260 \mathrm{c.}$

11. Адміністративне право України. Академічний курс : підруч. : у 2 т. ред. колегія : В. Б. Авер'янов (голова) та ін.; ТОВ «Видавництво «Юридична думка», 2007. Том 1. Загальна частина. 592 с.

12. Теорія держави і права : підруч. / О.В. Петришин, та ін. ; за ред. О.В. Петришина. Харків : Право, 2015. 368 с.

13. Демський Е. Ф. Адміністративно-процесуальне право України : навч. посібник. Київ : Юрінком Інтер, 2008. $496 \mathrm{c}$.

14. Кузьменко О.В. Курс адміністративного процесу : навч. посіб. Київ : Юрінком Інтер, 2012. 208 с.

15. Педько Ю.С. Становлення адміністративної юстиції в Україні : моногр. Київ : Ін-т держави і права ім. В. М. Корецького, 2003. 208 с.

16. Селіванов А.О. Адміністративний процес в Україні : реальність і перспективи розвитку правових доктрин. Київ : Вид. Дім «Ін Юре», 2000. 68 с.

17. Каган M.C. Избранные труды в VII томах. Tом I. Проблемы методологии. Санкт-Петербург : ИД «Петрополис», 2006 г. 356 с.

18. Ленівський Р.В. Законність і правопорядок в Україні: адміністративно-правові засоби забезпечення: дис. ... канд. юрид. наук : 12.00.07. ВНЗ «Відкритий міжнародний університет розвитку людини «Україна»; Нац. авіац. ун-т. Київ, 2018. 187 с.
19. Адміністративне право України. Повний курс: підручник / Галунько В., Діхтієвський П., Кузьменко О., Стеценко С. Херсон : ОЛДІ-ПЛЮС, 2018. 446 с.

\section{Анотація}

Лещинський В. П. Система гарантій законності дозвільної діяльності: засади та перспективи розвитку. - Стаття.

Стаття присвячена визначенню актуальних засад системи гарантій законності дозвільної діяльності з урахуванням специфіки сфери містобудування, визначенню на цій основі перспектив подальшого розвитку цієї системи. Доведено, що систему гарантій законності дозвільної діяльності становлять: загальносоціальні гарантії; юридичні гарантії. Особливою групою, що частково вбирає в себе загальносоціальні, а частково - юридичні гарантії, визначено міжнародні гарантії законності у сфері дозвільної діяльності. Загальносоціальними гарантіями законності у сфері дозвільної діяльності є: політичні, економічні, соціальні та ідеологічні гарантії. Юридичними гарантіями законності визначено юридичні умови, правові способи та організаційно-правові засоби. Міжнародні гарантії охарактеризовано як діяльність суб'єктів міжнародного права, спрямовану на охорону прав і свобод людини у сфері дозвільної діяльності. Окреслені гарантії мають охоронний характер, тобто спрямовані насамперед на запобігання протиправній діяльності у цій сфері. Окремою групою гарантій забезпечення законності у сфері дозвільної діяльності визначено захисні гарантії забезпечення законності у сфері дозвільної діяльності, що застосовуються у разі вчинення правопорушення. Доведено, що вони передбачені нормами як адміністративного матеріального права (адміністративна відповідальність), так і адміністративного процесуального права (адміністративні юрисдикційні провадження: судові та позасудові). Такі гарантії виділено у контексті насамперед дозвільної правозастосовної діяльності. Доведено, що позитивістські засади дозвільної діяльності зумовлюють особливе значення окремих юридичних гарантій законності у сфері дозвільної діяльності - юридичних умов (якісне законодавство) та правових засобів (контроль, в тому числі міжвідомчий, та нагляд у досліджуваній сфері). Уточнення місця та значення вказаних гарантій у виділеній системі визначено як перспективний напрям подальших наукових досліджень.

Ключові слова: містобудівна діяльність, містобудування, засади правового регулювання, правовий вплив, гарантії законності, дозвільна діяльність.

\section{Summary}

Leshchynskyi $V$.P. The system of guarantees of legality of permitting activity: principles and prospects of development. - Article.

The article is devoted to the definition of the current principles of the system of guarantees of legality of permitting activities taking into account the specifics of the field of urban planning, to determine on this basis the prospects for further development of this system. It is proved that the system of guarantees of legality of permitting activity consists of: general social guarantees; legal guarantees. A special group, which partly includes general social and partly legal guarantees, is defined as international guarantees of legality in the field of licensing. General social guarantees of legality in the field of licensing are defined as: political, economic, social and ideological guarantees. Legal conditions, legal methods and organizational and legal means are defined 
by legal guarantees of legality. International guarantees are described as the activities of subjects of international law aimed at protecting human rights and freedoms in the field of licensing. International guarantees are described as the activities of subjects of international law aimed at protecting human rights and freedoms in the field of licensing. A separate group of guarantees of legality in the field of licensing defines protective guarantees of legality in the field of licensing, which are used in case of an offense. It is proved that they are provided by the norms of both administrative substantive law (administrative liability) and administrative procedural law (administrative jurisdictional proceedings: judicial and extrajudicial).
Such guarantees are allocated in the context, first of all, of permitting law enforcement activity. It is proved that the positivist principles of permitting activity determine the special significance of certain legal guarantees of legality in the sphere of permitting activity - legal conditions (qualitative legislation) and legal means (control, including interdepartmental, and supervision in the researched sphere). Clarification of the place and significance of these guarantees in the selected system is defined as a promising area of further research.

Key words: town-planning activity, town-planning, principles of legal regulation, legal influence, guarantees of legality, permitting activity. 